\title{
PENGARUH GAYA MENGAJAR DAN MOTIVASI BELAJAR TERHADAP KETERAMPILAN SERVIS ATAS BOLA VOLI
}

\author{
${ }^{1}$ Ponidin, ${ }^{2}$ Aridhotul Haqiyah \& ${ }^{3}$ Dani Nur Riyadi \\ e-mail: ponidin26@gmail.com \\ ${ }^{1}$ Guru SMP Negeri 277 Jakarta \\ 2,3Universitas Islam 45 Bekasi
}

\begin{abstract}
Abstrak: Tujuan dari penelitian ini adalah untuk mengetahui pengaruh manakah yang lebih efektif antara penerapan gaya mengajar inklusi dan komando terhadap keterampilan servis atas bola voli jika dikaitkan dengan faktor motivasi belajar pada siswa SMP Negeri 277 Jakarta. Penelitian dilakukan dari bulan Mei sampai Juni 2016. Metode yang digunakan dalam penelitian ini dengan menggunakan metode eksperimen. Desain penelitian yang digunakan adalah desain treatment by level $2 \times 2$. Penelitian ini dilaksanakan di SMP Negeri 277 Jakarta dengan populasi seluruh siswa kelas VIII dengan jumlah 252 orang yang tersebar di 7 kelompok belajar. Teknik pengambilan sampel dalam penelitian ini adalah cluster sampling. Dari 7 kelompok belajar tersebut, dipilih dua kelas untuk diberikan perlakuan atau program pembelajaran. Satu kelas terdiri atas 36 siswa. Jadi, sampel dalam penelitian ini berjumlah 72 siswa. Penentuan kelompok dilakukan dengan penyebaran kuesioner motivasi belajar. Skor yang diperoleh dari pengukuran dalam satu kelas kemudian diranking dari nilai tertinggi ke rendah. Kelompok belajar pertama diajar dengan gaya mengajar inklusi (A1) dan kelompok belajar kedua diajar dengan gaya mengajar komando (A2). Instrumen yang digunakan adalah tes servis atas bola voli. Berdasarkan hasil pengolahan dan analisis data, kesimpulan hasil penelitian ini adalah (1) secara keseluruhan terdapat perbedaan keterampilan servis atas bola voli antara siswa yang diajar dengan gaya mengajar inklusi dan siswa yang diajar dengan gaya mengajar komando; (2) terdapat interaksi antara gaya mengajar dan motivasi belajar terhadap keterampilan servis atas bola voli; (3) bagi kelompok siswa yang memiliki tingkat motivasi belajar tinggi, keterampilan servis atas bola voli lebih tinggi bila diajar dengan gaya mengajar inklusi; dan (4) bagi kelompok siswa yang memiliki tingkat motivasi belajar rendah, keterampilan servis atas bola voli lebih tinggi bila diajar dengan gaya mengajar komando.
\end{abstract}

Kata kunci: gaya mengajar, inklusi, komando, servis atas bola voli.

\section{THE EFFECT OF INCLUSSION, COMMAND, AND MOTIVATION TEACHING METHODE FOR VOLLEYBALL UP SERVICE SKILL}

\begin{abstract}
The purpose of this research is to determine the more effective teaching style between the application of inclusions teaching styles and command teaching styles for skills of volleyball up service if each of them is associated with learning motivational factors in 277 Government Junior High School, Jakarta. The study was conducted from May to June 2016. This research used an experimental method and a treatment by level $2 x 2$ design. The research conducted in 277 Government Junior High School, Jakarta including all students of grade VIII with total of 252 students spread in 7 classes. Employing cluster sampling technique, this research selected two classes to be given treatments or learning programs. One class consisted of 36 students making the total sample to be 72 people. The instrument used in this research was a volleyball up service test. The conclusions of this study are (1) overall, there are different volleyball up service skills among the students who are taught by inclusions teaching style and students who are taught by commands teaching style; (2) there are interactions between teaching style and motivation to learn with the skills of volleyball up service; (3) for the group of students who have high learning motivation level, the up service skills on a volleyball higher when taught by the inclusions teaching style; and (4) for the group of students who have low motivation learning levels, skills on the volleyball serve higher when taught by the commands teaching style.
\end{abstract}

Keywords : teaching style, inclusion, command, volleyball up service. 


\section{PENDAHULUAN}

Pendidikan jasmani olahraga dan kesehatan (Penjasorkes) adalah kelompok mata pelajaran yang diajarkan dari jenjang pendidikan dasar sampai pendidikan atas atau kejuruan melalui aktivitas fisik. Penjasorkes diharapkan dapat mendorong pertumbuhan fisik, perkembangan psikis, keterampilan motorik, pengetahuan dan penalaran, penghayatan nilai-nilai serta pembiasaan hidup sehat untuk merangsang pertumbuhan dan perkembangan kualitas fisik dan psikis yang seimbang.

Dalam proses pembelajaran pendidikan jasmani, guru diharapkan dapat mengajarkan berbagai keterampilan gerak dasar, teknik dan strategi permainan dan olahraga, internalisasi nilainilai (sportivitas, jujur, kerjasama, tanggung jawab dan lain-lain ) serta pembiasaan pola hidup sehat. Pada pelaksanaannya bukan melalui pengajaran konvensional di dalam kelas yang bersifat kajian teoretik, namun melibatkan unsur fisik, mental, intelektual, emosional, dan sosial.

Menurut Syah (2007: 132), terdapat beberapa faktor yang berpengaruh dalam proses pembelajaran, diantaranya (1) faktor internal yang berupa kondisi fisik atau jasmani; (2) faktor eksternal yang berupa lingkungan belajar; serta (3) faktor pendekatan belajar yang berupa metode maupun strategi belajar.

Dalam interaksi belajar dan pembelajaran berbagai gaya mengajar yang diterapkan oleh guru tentunya memegang peranan yang sangat penting. Gaya mengajar dalam kegiatan pembelajaran sangat bervariasi, pemilihannya disesuaikan dengan tujuan yang hendak dicapai. Seorang guru tidak dapat melaksanakan tugasnya dengan baik apabila tidak menguasai satu atau beberapa gaya mengajar. Untuk pencapaian tujuan pembelajaran, pemilihan gaya mengajar harus tepat. Dengan demikian diharapkan kegiatan pembelajaran dapat berlangsung secara baik dan bernilai guna.

Dalam proses mengajar, seorang pendidik tidak harus terpaku pada penggunaan satu gaya mengajar, akan tetapi harus menggunakan beberapa gaya mengajar yang digunakan secara bervariasi agar pembelajaran tidak membosankan. Penggunaan gaya yang bervariasi tidak akan menguntungkan proses interaksi belajar dan pembelajaran apabila penggunaan gaya tidak tepat dengan situasi kegiatan belajar dan pembelajaran. Disinilah dituntut kompetensi guru dalam pemilihan gaya mengajar yang tepat. Aktivitas yang diberikan dalam pembelajaran harus mendapatkan sentuhan didaktik metodik, sehingga aktivitas yang dilakukan dapat mencapai tujuan pengajaran.

Penggunaan istilah gaya mengajar (teaching style) sering berganti dengan istilah mengajar (teaching strategy) yang pengertiannya dianggap sama, yakni siasat untuk menggiatkan partisipasi siswa untuk melaksanakan tugas-tugas ajar. Hal ini dikaitkan dengan upaya untuk mengelola lingkungan dan atmosfir pengajaran untuk tujuan mengoptimalkan jumlah waktu aktif berlatih dari para siswa yang dipandang sebagai indikator tercapainya menilai keefektifan pengajaran.

Berdasarkan observasi yang dilakukan, siswa sangat meminati permainan bola besar, terutama bola voli. Tetapi yang menjadi permasalahan adalah siswa masih belum menguasai teknik dasar permainan bola voli yaitu servis atas. Teknik dasar servis atas bola voli termasuk dalam materi pembelajaran yang harus disampaikan dalam kurikulum pendidikan jasmani, jadi hal terpenting dari servis atas adalah kemampuan peserta didik dalam melewatkan bola ke lapangan lawan dengan baik. Servis adalah salah satu teknik dasar dalam permainan bola voli, selain itu servis juga dijadikan sebagai suatu serangan terhadap lawan untuk mendapatkan poin tambahan.

Sejalan dengan tujuan yang ingin dicapai pembelajaran bola voli khususnya materi servis atas, seorang guru harus bisa memilih gaya mengajar yang sesuai dengan tujuan yang akan dicapai. Ada banyak gaya mengajar yang dapat meningkatkan penguasaan keterampilan servis atas. Bentuk gaya mengajar untuk menguasai materi servis atas diantaranya adalah gaya mengajar inklusi dan gaya mengajar komando.

Dengan melihat hasil observasi di lapangan pada siswa kelas VIII SMP Negeri 277 Jakarta yang masih mengalami kesulitan dalam melakukan servis atas, hal ini mungkin disebabkan oleh penggunaan gaya mengajar yang tidak sesuai saat pemberian materi servis atas dan motivasi belajar anak saat pembelajaran kurang tepat. Dengan latar belakang tersebut, maka penulis mencoba melakukan penelitian dengan judul Pengaruh Gaya Mengajar Inklusi, Komando, dan Motivasi Belajar terhadap Keterampilan Servis atas Bolavoli.

Menurut Mukholid (2007: 7), servis adalah pukulan permulaan untuk memulai permainan yang dilakukan dari daerah servis di belakang lapangan. Servis pada saat ini bukan saja berfungsi sebagai pembuka permainan melainkan sebagai serangan awal bagi regu yang melakukan servis. Kedudukan servis menjadi sangat penting, karena peraturan 
pertandingan yang berlaku saat ini menggunakan sistem rally point yaitu setiap perpindahan bola maupun bola mati menghasilkan point bagi regu yang memenangkan rally atau mematikan bola di lapangan lawan, sehingga dengan service yang sempurna akan dapat langsung mengumpulkan angka tanpa ada rally-rally.

Servis atas adalah sebuah tindakan oleh seorang pemain belakang (posisi 1) untuk memukul bola dengan cara melemparkan bola ke atas lalu memukulnya dengan mengayunkan tangan dari atas dengan tenaga maksimal sehingga bola meluncur dengan cepat mengenai lapangan tim lawan. Servis atas dilakukan dari garis belakang lapangan permainan dengan memperhatikan peraturanperaturan servis yang berlaku. Kesalahan servis atas biasanya dilakukan tidak sengaja, misalnya pukulan terlalu kuat atau terlalu lemah sehingga bola keluar atau tidak melewati net. Menurut Lenberg (2006), tahapan dalam melakukan gerakan servis atas adalah (1) sikap awal; (2) sikap melempar bola; (3) sikap memukul bola; dan (4) sikap akhir.

Beberapa pendapat para ahli mengatakan bahwa mengajar inklusi adalah suatu gaya mengajar yang dalam pelaksanaannya melalui proses tahapan atau tingkatan yang memberikan kebebasan kepada peserta didik untuk menilai sendiri kemampuan yang dilakukan dan dipelajari.

Gaya mengajar inklusi adalah suatu gaya mengajar dengan cara menyajikan materi pembelajaran secara rinci dan menawarkan tingkattingkat kesulitan yang berbeda secara berurutan, yang bertujuan agar siswa kreatif dan mendapatkan kemudahan dalam mempelajari suatu keterampilan gerak, juga siswa diberi kebebasan untuk memilih dan menentukan pada tingkat kesulitan mana untuk memulai belajar suatu gerakan, serta diberi kebebasan dan keleluasaan pula untuk menentukan berapa kali siswa harus mengulangi gerakan, dalam mempelajari suatu teknik gerakan dalam setiap pertemuan.

Tujuan gaya mengajar inklusi menurut Mosston (2008: 156) adalah (1) melibatkan semua siswa; (2) penyesuaian terhadap perbedaan individu; (3) memberi kesempatan untuk memulai pada tingkat kemampuan sendiri; (4) memberi kesempatan untuk memulai bekerja dengan tugas-tugas yang ringan ke berat, sesuai dengan tingkat kemampuan siswa; (5) belajar melihat hubungan antara kemampuan dan tugas apa yang dapat dilakukan siswa; (6) individualisasi dimungkinkan karena memilih di antara alternatif tingkat tugas yang telah disediakan.

Karakteristik gaya inklusi yang dikembangkan
Mosston (2008: 156) yaitu (1) tugas yang disusun sama tetapi derajat kesukarannya berbeda; (2) peserta didik menentukan sendiri tingkatnya dalam tugas; serta (3) tingkat-tingkat keterampilan bagi semua peserta didik tercakup.

Peserta didik belajar untuk menentukan keputusan sendiri dan bertanggung jawab, dengan mencerminkan sikap percaya diri. Keberhasilan proses belajar dan pembelajaran ditentukan sendiri, sehingga membuka peluang dalam menyelesaikan tugas lebih cepat dari yang ditentukan, dan pengajar hanya berperan sebagai pengawas dan menilai hasil dan kemampuan peserta didik dalam setiap tugas. Pengajar menentukan tugas pembelajaran yang memiliki target atau kriteria yang berbeda tingkat kesulitannya, dan peserta didik diberi keleluasaan untuk tugas mana yang sesuai.

Gaya mengajar inklusi memiliki pandangan akan perbedaan karakter pada masing-masing individu, terutama yang berhubungan dengan motivasi peserta didik. Peran seorang pengajar dalam gaya ini adalah untuk membuat keputusan sebelum pertemuan.

Anatomi dari gaya mengajar inklusi adalah sebagai berikut (1) peranan pengajar : membuat keputusan kepada peserta didik pada pra pertemuan dan harus merencanakan seperangkat tugas-tugas dalam berbagai tingkat kesulitan yang disesuaikan dengan perbedaan individu dan yang memungkinkan peserta didik untuk beranjak dari tugas yang mudah ke tugas yang sulit; serta (2) keputusan-keputusan peserta didik : memilih tugas yang tersedia, melakukan penafsiran sendiri dan memilih tugas awalnya, peserta didik mencoba tugasnya, dan menentukan untuk mengulang memilih tugas yang lebih sulit atau lebih mudah berdasarkan hasil tugas awal, mencoba tugas berikutnya.

Gaya mengajar inklusi dapat dilaksanakan dengan cara: (1) memberi penjelasan gaya inklusi pada siswa; (2) melalui demonstrasi dengan melakukan teknik servis atas yang sangat baik; (3) siswa diberi aba-aba untuk memulai; (4) mengamati siswa; (5) memberi umpan balik kepada siswa tentang tentang peranan pengambilan keputusan dan bukan penampilan tugas.

Berdasarkan penjelasan di atas yang dimaksud dengan gaya mengajar inklusi adalah gaya mengajar yang dalam pelaksanaannya melalui proses tahapan atau tingkatan yang memberikan kebebasan kepada peserta didik untuk menilai sendiri kemampuan yang dilakukan atau dipelajari.

Peranan guru dalam proses belajar dan 
pembelajaran menggunakan gaya mengajar komando sangat dominan, semua keputusan dikontrol oleh guru sehingga setiap gerakan yang dilakukan peserta didik berdasarkan model yang dicontohkan oleh guru. Artinya esensi dari gaya mengajar komando adalah adanya hubungan langsung dan segera antara stimulus dari guru dengan respons oleh siswa. Stimulus berupa isyarat dan perintah dari guru yang harus dapat diterjemahkan oleh siswa melalui gerakan, setiap gerakan yang dilakukan oleh peserta didik selalu mengikuti model/contoh yang dilakukan oleh guru.

Berdasarkan anatomi gaya mengajar komando, yang dominan mengambil keputusan pada sebelum pertemuan, pertemuan dan setelah pertemuan adalah guru. Gaya mengajar komando ini dilandasi oleh teori belajar stimulus-respons, yaitu guru memberikan stimulus $X$ maka akan menghasilkan respons $Y$ pada diri peserta didik. Keterampilan motorik akan diperoleh apabila peserta didik melakukan serangkaian stimilus respons secara berulang-ulang sehingga akan menghasilkan respons yang benar.

Keuntungan menggunakan gaya mengajar komando adalah akan diperolehnya keseragaman bentuk gerakan dan kedisiplinan siswa karena penggunaan gaya mengajar komando dalam proses belajar dan pembelajaran seluruhnya dikontrol oleh guru. Sedangkan kelemahan atau kerugian menggunakan gaya mengajar komando adalah (1) tidak dapat terakomodasinya berbagai kebutuhan berdasarkan perbedaan individu; (2) menghambat kreativitas siswa; (3) jika contoh gerakan yang diberikan tidak hati-hati dan cermat, akan menimbulkan rasa tidak puas; (4) contoh gerakan yang salah akan menjadi sumber ejekan peserta didik kepada gurunya, dan yang lebih fatal adalah peserta didik akan mengikuti sehingga menimbulkan keterampilan yang salah pula; serta (5) akan menghilangkan kegairahan atau motivasi peserta didik untuk berlatih atau belajar di luar jam pelajaran.

Selain faktor eksternal berupa penerapan gaya mengajar guru penjasorkes, faktor internal juga ikut mempengaruhi hasil belajar siswa, salah satunya adalah motivasi belajar siswa. Menurut vroom dalam Purwanto (2007: 72), motivasi mengacu kepada suatu proses mempengaruhi pilihanpilihan individu terhadap bermacam-macam bentuk kegiatan yang dikehendaki. Istilah motivasi mencakup konsep dorongan (drive), kebutuhan (need), rangsangan (incentive), ganjaran (reward), penguatan (reinforcement), ketetapan tujuan (goal setting) harapan (expectancy) dan sebagainya.

Menurut Tangkudung (2012: 21), masalah kebutuhan individu merupakan dasar yang menimbulkan perbedaan tingkah laku individu, dimana individu bertingkah karena adanya dorongan untuk memenuhi kebutuhan. Konsep yang berkaitan dengan motivasi adalah konsep "needs" atau kebutuhan. Hirarki kebutuhan dapat dipakai untuk melukiskan dan meramalkan tinggi rendahnya motivasi.

Maslow dalam Sobur (2013: 274-279) menggolongkan kebutuhan manusia pada lima tingkat kebutuhan (five hierarchy of needs), yaitu (1) kebutuhan fisiologis (physiological needs) merupakan kebutuhan pokok manusia untuk memelihara kelangsungan hidupnya, seperti kebutuhan sandang, pangan, perumahan, air, seks dan sebagainya; (2) kebutuhan rasa aman (safety needs) merupakan kebutuhan ingin dilindungi, seperti keamanan dalam bekerja, keamanan hidup dan sebagainya; (3) kebutuhan sosial (social needs) merupakan kebutuhan untuk diterima dan dihargai oleh orang lain, saling mencintai, saling menghargai, bekerjasama, tolong-menolong, dan sebagainya; (4) kebutuhan penghargaan (eksteem needs) merupakan kebutuhan akan harga diri, percaya diri, prestise, dan kekuasaan; dan (5) kebutuhan aktualisaasi (self actualization) merupakan kebutuhan untuk mengembangkan kemampuan diri secara optimal sehingga mampu berbuat yang lebih baik, berprestasi dan kreatif.

Dengan demikian, motivasi belajar itu bersumber dari dalam diri individu untuk mendorong individu tersebut untuk mencapai keberhasilan yang diinginkan dengan standar terbaik. Motivasi belajar adalah suatu keinginan atau kebutuhan dari dalam individu untuk mencapai hasil terbaik. Bila ditinjau dari sumber timbulnya motivasi seseorang, motivasi dapat intrinsik dan ekstrinsik. Motivasi intrinsik berasal dari dalam individu yang berupa kecakapan dan untuk melakukan sesuatu demi memenuhi keinginannya, sedangkan motivasi ekstrinsik adalah motivasi yang berasal dari luar individu seperti pujian dan ganjaran.

Seseorang yang memiliki motivasi belajar tinggi cenderung memilih tugas-tugas yang sulit dan menantang yang terkadang berada di luar batas kemampuannya, sebaliknya orang yang memiliki motivasi belajar rendah cenderung memilih yang mudah dan kurang menantang. Seseorang yang memiliki motivasi berprestasi tinggi, pada umumnya mempunyai keinginan yang tinggi untuk sukses dan keinginan sama besarnya dengan ketakutan 
pada kegagalan. Di samping itu, lebih menyukai kegiatan-kegiatan yang sulit dan menantang, berani mengambil resiko, sanggup mengambil alih pekerjaan dalam tugas, bertanggung jawab, menyukai keunikan, gelisah bila terjadi kegagalan, serta cenderung menonjolkan diri.

Penyebab dorongan untuk bertindak itu dapat berasal dari dalam diri siswa (intrinsik) maupun dari luar diri siswa (ekstrinsik). Motivasi belajar akan diukur melalui skala yang menggambarkan dorongan untuk melakukan tugas dalam suatu proses pendidikan. Pada skala yang digunakan makin tinggi skor atau nilai yang diperoleh makin tinggi pula tingkat motivasi belajar. Dari teori yang dikemukakan di atas dapat disimpulkan bahwa motivasi adalah suatu keinginan atau hasrat yang terdapat pada diri seseorang terhadap suatu kegiatan tertentu.

\section{METODE PENELITIAN}

Metode yang digunakan dalam penelitian ini dengan menggunakan metode eksperimen. Desain penelitian yang digunakan adalah desain treatment by level $2 \times 2$. Desain treatment by level merupakan suatu tindakan terhadap satu variabel atau lebih yang dimanipulasi secara simultan agar dapat mempelajari pengaruh setiap variabel terhadap variabel terikat atau pengaruh yang diakibatkan adanya interaksi antara beberapa variabel. Rancangan faktorial adalah unit-unit eksperimen ke dalam sel sedemikian rupa secara acak, sehingga setiap unit-unit eksperimen dalam setiap sel relatif homogen.

Secara rinci rancangan desain treatment by level $2 \times 2$ penelitian dapat dilihat pada tabel di bawah ini:

Tabel 1. Desain Treatment by Level 2 X 2

\begin{tabular}{ccc}
\hline \multirow{2}{*}{ Motivasi Belajar (B) } & \multicolumn{2}{c}{ Gaya Mengajar (A) } \\
\cline { 2 - 3 } Motivasi Belajar Tinggi (B1) & Inklusi (A1) & Komando (A2) \\
Motivasi Belajar Rendah (B2) & A1B2 & A2B1 \\
\hline
\end{tabular}

Dalam penelitian ini, populasinya adalah seluruh siswa kelas VIII SMP Negeri 277 Jakarta yang berjumlah 252 orang yang tersebar menjadi 7 kelas. Waktu penelitian berlangsung selama 2 bulan terhitung dari bulan Mei-Juni 2016.Teknik pengambilan sampel dalam penelitian ini adalah cluster sample. Dari 7 kelas VIII SMP Negeri 277 Jakarta tersebut, dipilih dua kelas untuk diberikan treatment atau program pembelajaran. Satu kelas terdiri dari 36 siswa. Jadi sampel dalam penelitian ini berjumlah 72 orang. Penentuan kelompok dilakukan dengan penyebaran angket motivasi belajar. Skor yang diperoleh dari pengukuran dalam satu kelas kemudian diranking dari nilai tertinggi ke rendah. Kelas pertama yang diajar dengan gaya mengajar inklusi (A1) kelas kedua diajar dengan gaya mengajar komando (A2).

Tabel 2. Pengelompokan Subjek Penelitian

\begin{tabular}{lcc}
\hline \multirow{2}{*}{ Motivasi Belajar (B) } & \multicolumn{2}{c}{ Gaya Mengajar (A) } \\
\cline { 2 - 3 } & Inklusi (A1) & Komando (A2) \\
\hline Motivasi Belajar Tinggi (B1) & 18 & 18 \\
Motivasi Belajar Rendah (B2) & 18 & 18 \\
Keseluruhan & 36 & 36 \\
\hline
\end{tabular}

Rancangan perlakuan menggunakan 2 bentuk gaya mengajar, yaitu gaya mengajar inklusi dan komando. Gaya mengajar inklusi adalah suatu gaya pembelajaran dengan cara menyajikan materi pembelajaran secara rinci dan menawarkan tingkattingkat kesulitan yang berbeda secara berurutan, yang bertujuan agar siswa kreatif dan mendapatkan kemudahan dalam mempelajari suatu keterampilan gerak, juga siswa diberi kebebasan untuk memilih dan menentukan pada tingkat kesulitan yang sesuai untuk memulai belajar suatu gerakan, sedangkan gaya mengajar komando ini dilandasi oleh teori belajar stimulus-respons, yaitu guru memberikan stimulus $X$ maka akan menghasilkan respons $Y$ pada diri peserta didik.

Instrumen yang digunakan adalah tes keterampilan servis atas bola voli, sedangkan instrumen motivasi belajar diukur menggunakan angket skala likert. Adapun kisi-kisinya adalah sebagai berikut:

Tabel 3. Kisi-kisi Instrumen Motivasi Berprestasi

\begin{tabular}{|c|c|c|c|}
\hline Dimensi & Indikator & $\begin{array}{l}\text { Nomor } \\
\text { Butir }\end{array}$ & Jumlah \\
\hline & $\begin{array}{l}\text { 1. Menerima kritik dan mengakui } \\
\text { kekurangan. }\end{array}$ & $\begin{array}{l}1,2,4,10 \\
15,23\end{array}$ & 6 \\
\hline Motivasi & 2. Berani mengambil resiko & $13,20,26$ & 3 \\
\hline \multirow[t]{6}{*}{ Intrinsik } & 3. Tanggung jawab & 11,19 & 2 \\
\hline & 4. Waktu penyelesaian tugas & 9 & 1 \\
\hline & $\begin{array}{l}\text { 5. Keinginan untuk sukses dan } \\
\text { tebaik }\end{array}$ & $6,12,16,21$ & 4 \\
\hline & 6. Bersemangat tinggi dan disiplin & $5,18,24$ & 3 \\
\hline & 7. Kreatif dan inovatif & $7,8,17$ & 3 \\
\hline & $\begin{array}{l}\text { 8. Mempunyai perasaan takut } \\
\text { gagal }\end{array}$ & 3,14 & 2 \\
\hline Motivasi & 1. Pengaruh lingkungan & 30 & 1 \\
\hline \multirow[t]{3}{*}{ Ekstrinsik } & 2. Pemberian penghargaan & $22,27,28$ & 3 \\
\hline & 3. Perintah guru/pelatih & 29 & 1 \\
\hline & 4. Aktualisasi diri & 25 & 1 \\
\hline \multicolumn{3}{|c|}{ Jumlah } & 30 \\
\hline
\end{tabular}




\section{HASIL DAN PEMBAHASAN}

Sampel dalam penelitian siswa SMP Negeri 277 Jakarta sebanyak 72 orang. Untuk hasil penghitungan statistik deskriptif dapat dilihat pada tabel di bawah ini:

Tabel 4. Hasil Penghitungan Statistik Deskriptif
Descriptive Statistics

Dependent Variable: Keterampilan Servis Atas Bola Voli

\begin{tabular}{|c|c|c|c|c|}
\hline A & B & Mean & $\begin{array}{c}\text { Std. } \\
\text { Deviation }\end{array}$ & $\mathrm{N}$ \\
\hline \multirow{5}{*}{$\begin{array}{c}\text { Gaya } \\
\text { Mengajar } \\
\text { Inklusi }\end{array}$} & Motivasi & 39.78 & 4.373 & 18 \\
\hline & Belajar Tinggi & & & \\
\hline & Motivasi & 30.44 & 1.381 & 18 \\
\hline & Belajar Rendah & & & \\
\hline & Total & 35.11 & 5.711 & 36 \\
\hline \multirow{5}{*}{$\begin{array}{c}\text { Gaya } \\
\text { Mengajar } \\
\text { Komando }\end{array}$} & Motivasi & 26.56 & 2.229 & 18 \\
\hline & Belajar Tinggi & & & \\
\hline & Motivasi & 34.33 & 1.645 & 18 \\
\hline & Belajar Rendah & & & \\
\hline & Total & 30.44 & 4.391 & 36 \\
\hline \multirow[t]{5}{*}{ Total } & Motivasi & 33.17 & 7.527 & 36 \\
\hline & Belajar Tinggi & & & \\
\hline & Motivasi & 32.39 & 2.476 & 36 \\
\hline & Belajar Rendah & & & \\
\hline & Total & 32.78 & 5.577 & 72 \\
\hline
\end{tabular}

Sebelum dilakukan analisis Varian (Anava), terlebih dahulu dilakukan uji persyaratan analisis, yaitu (1) uji normalitas; dan (2) uji homogenitas populasi. Adapun hasilnya adalah sebagai berikut:

Tabel 5. Ringkasan Uji Normalitas Data

\begin{tabular}{ccccccc}
\hline \multicolumn{3}{c}{ Kolmogorov-Smirnova } & \multicolumn{4}{c}{ Shapiro-Wilk } \\
\hline & Statistic & $\mathrm{df}$ & Sig. & Statistic & $\mathrm{df}$ & Sig. \\
$\mathrm{A} 1 \mathrm{~B} 1$ & .182 & 18 & .120 & .904 & 18 & .068 \\
$\mathrm{~A} 2 \mathrm{~B} 1$ & .186 & 18 & .100 & .944 & 18 & .341 \\
$\mathrm{~A} 1 \mathrm{~B} 2$ & .156 & 18 & $.200^{*}$ & .892 & 18 & .041 \\
$\mathrm{~A} 2 \mathrm{~B} 2$ & .176 & 18 & .146 & .913 & 18 & .096 \\
\hline \multicolumn{4}{c}{ a. Lilliefors Significance Correction } \\
$*$ * This is a lower bound of the true significance.
\end{tabular}

Berdasarkan hasil pengujian normalitas data, diketahui bahwa nilai signifikansi seluruh variabel lebih besar dari 0,05 maka dapat disimpulkan bahwa semua data pada kelompok penelitian berdistribusi Normal. Sedangkan hasil pengujian homogenitas data dapat dilihat pada tabel di bawah ini:

Tabel 6. Hasil Penghitungan Uji Homogenitas Data

Test of Homogeneity of Variances

Keterampilan Servis Atas Bola Voli

\begin{tabular}{cccc}
\hline Levene Statistic & df1 & df2 & Sig. \\
\hline 5.553 & 3 & 68 & .062 \\
\hline
\end{tabular}

Tabel 7. Hasil Penghitungan ANOVA

Keterampilan Servis Atas Bola Voli

\begin{tabular}{cccccc}
\hline & $\begin{array}{c}\text { Sum of } \\
\text { Squares }\end{array}$ & df & $\begin{array}{c}\text { Mean } \\
\text { Square }\end{array}$ & F & Sig. \\
\hline $\begin{array}{c}\text { Between } \\
\text { Groups }\end{array}$ & 1720.444 & 3 & 573.481 & 79.911 & .000 \\
$\begin{array}{c}\text { Within } \\
\text { Groups } \\
\text { Total }\end{array}$ & 488.000 & 68 & 7.176 & & \\
\hline
\end{tabular}

Berdasarkan analisis pada tabel Test of Homogeneity of Variances diperoleh $\mathrm{F}=5,553 ; \mathrm{df} 1=3$, $\mathrm{df} 2=68$, dan $\mathrm{p}$-value $=0,062>0,05$ atau H0 diterima. Dengan demikian data keterampilan servis atas bola voli dari keempat kelompok homogen. Sedangkan tabel ANOVA diperoleh harga $\mathrm{F}=79,911$ dan $p$-value $=$ $0,000<0,05$ yang berarti terdapat perbedaan rata-rata keterampilan servis atas bola voli yang signifikan dari keempat kelompok perlakuan.

\section{Pengujian Hipotesis}

Berdasarkan hasil penghitungan uji hipotesis, keempat hipotesis yang diajukan adalah terbukti. adapun rangkumannya adalah sebagai berikut:

Tabel 8. Rangkuman Penghitungan Uji Hipotesis Pertama dan Kedua

\begin{tabular}{cccc}
\hline Hipotesis yang Diuji & $\begin{array}{c}F \\
\text { hitung }\end{array}$ & p-value & Keterangan \\
\hline H1 : $\mu \mathrm{A} 1>\mu \mathrm{A} 2$ & 54,623 & 0,000 & Sig \\
H1 : Interaksi A X B & 183.594 & 0,000 & Sig \\
$\quad \neq 0$ & & & \\
\hline
\end{tabular}

Tabel 9. Rangkuman Penghitungan Uji Hipotesis Ketiga dan Keempat

\begin{tabular}{lccc}
\hline Hipotesis yang Diuji & $\begin{array}{c}\text { Mean } \\
\text { Different }\end{array}$ & p-value & Keterangan \\
\hline $\mathrm{H} 1: \mu \mathrm{A} 1 \mathrm{~B} 1>\mu \mathrm{A} 2 \mathrm{~B} 1$ & 13,222 & 0,000 & Sig \\
$\mathrm{H} 1: \mu \mathrm{A} 1 \mathrm{~B} 2<\mu \mathrm{A} 2 \mathrm{~B} 2$ & $-3,889$. & 0,000 & Sig \\
\hline
\end{tabular}

Berdasarkan data hasil penelitian, terdapat perbedaan nilai rata-rata skor keterampilan servis atas bola voli dalam penerapan gaya mengajar inklusi dan komando. Pada gaya mengajar inklusi diperoleh nilai rata-rata lebih besar, yaitu 35,11 jika dibandingkan dengan nilai rata-rata gaya mengajar komando, yaitu 30,44 .

Dari hasil penghitungan uji turkey pada hipotesis pertama diperoleh nilai sig $=0,000<0,05$, atau $\mathrm{H} 0$ ditolak. Hal ini berarti terdapat perbedaan rata-rata keterampilan servis atas bola voli antara siswa yang diajar dengan gaya mengajar inklusi maupun komando. Perbedaan ini disebabkan karena 
pada gaya mengajar inklusi memiliki kelebihan dalam pelaksanaannya, yaitu memberikan kebebasan kepada peserta didik untuk menilai sendiri kemampuan yang dilakukan atau dipelajari. Jika dibandingkan dengan gaya mengajar komando, maka gaya mengajar inklusi memberikan hasil yang lebih baik dalam meningkatkan keterampilan servis atas bola voli.

Sesuai uraian dan pembahasan tentang keunggulan gaya mengajar inklusi dan komando, maka secara keseluruhan gaya mengajar inklusi lebih baik daripada gaya mengajar komando dalam meningkatkan keterampilan servis atas bola voli pada siswa. Desain faktorial dalam penelitian memberikan kemungkinan kepada peneliti untuk menilai interaksi antara kedua variabel bebas, yaitu pengaruh yang berbeda dari salah satu di antara kedua variabel pada tingkat yang berbedadari variabel lainnya.

Berkaitan dengan variabel interaksi, hasil pengujian hipotesis kedua menunjukkan bahwa terdapat interaksi antara gaya mengajar dan motivasi belajar terhadap keterampilan servis atas bola voli dengan nilai Sig $=0,000<0,05$, atau H0 ditolak. Hal ini berarti ada pengaruh interaksi yang sangat signifikan antara faktor A (gaya mengajar) dan faktor B (motivasi belajar) terhadap keterampilan servis atas bola voli siswa. Tampak dari hasil analisis bahwa besar pengaruh gaya mengajar dan motivasi belajar terhadap keterampilan servis atas bola voli sebesar $77,9 \%$.

Wujud interaksi yang ditunjukkan oleh hasil penghitungan ini memberikan alasan yang jelas bahwa dengan keragaman karakteristik dan motivasi belajar siswa akan berdampak pada pemilihan gaya mengajar yang tepat. Dengan demikian, antara gaya mengajar dan motivasi belajar akan saling mempengaruhi dan berinteraksi secara positif dalam proses pembelajaran dalam meningkatkan keterampilan servis atas bola voli.

Pada tingkat motivasi belajar tinggi dengan gaya mengajar inklusi, diperoleh nilai rata-rata siswa dalam melakukan servis atas bola voli sebesar 39,78 yang berarti lebih tinggi dari nilai rata-rata siswa dengan gaya mengajar komando, yaitu 26,56. Berdasarkan uji turkey diketahui bahwa perbedaan keterampilan servis atas bola voli $(\mathrm{Y})$ antara siswa yang diajar dengan gaya mengajar inklusi (A1) dan siswa yang diajar dengan gaya mengajar komando (A2) pada kelompok siswa yang memiliki motivasi belajar yang tinggi (B1), mempunyai nilai sig 0,000 $<0,05$ sehingga $\mathrm{H} 0$ ditolak. Artinya rata-rata hasil keterampilan servis atas bola voli kelompok siswa yang diajar dengan gaya mengajar inklusi lebih tinggi daripada kelompok yang diajar dengan gaya mengajar komando untuk siswa yang memiliki motivasi belajar tinggi. Dimana perbedaannya (mean difference) sebesar 13,222.

Hal ini membuktikan hipotesis alternatif ketiga, yaitu $\mathrm{H} 1: \mu \mathrm{A} 1 \mathrm{~B} 1>\mu \mathrm{A} 2 \mathrm{~B} 1$ yang berarti bahwa siswa yang memiliki motivasi belajar tinggi dengan diberikan gaya mengajar inklusi akan memperoleh hasil servis atas bola voli yang lebih baik daripada diajar dengan gaya mengajar komando. Dalam konteks ini dapat dimaknai bahwa kelebihan gaya mengajar inklusi sangat berpengaruh terhadap keterampilan servis atas bola voli, penerapan gaya mengajar inklusi akan lebih efektif apabila diikuti oleh motivasi belajar yang tinggi dalam proses pembelajaran.

Pada tingkat motivasi berprestasi yang rendah siswa yang diajar dengan gaya mengajar inklusi, diperoleh nilai rata-rata siswa dalam melakukan servis atas bola voli sebesar 30,44 yang berarti lebih rendah dari nilai rata-rata siswa yang diajar dengan gaya mengajar komando, yaitu 34,33.

Berdasarkan uji turkey diketahui bahwa perbedaan keterampilan servis atas bola voli $(\mathrm{Y})$ antara siswa yang diajar dengan gaya mengajar inklusi (A1) dan siswa yang diajar dengan gaya mengajar komando (A2) pada kelompok siswa yang memiliki motivasi belajar yang rendah (B2) mempunyai nilai sig $0,000<0,05$ sehingga $\mathrm{H} 0$ ditolak. Artinya rata-rata hasil keterampilan servis atas bola voli kelompok siswa yang diajar dengan gaya mengajar inklusi lebih rendah daripada kelompok yang diajar dengan gaya mengajar komando untuk siswa yang memiliki motivasi belajar rendah. Dimana perbedaannya (mean difference) sebesar $-3,889$

Hal ini membuktikan hipotesis alternatif keempat, yaitu $\mathrm{H} 1 \quad \mu \mathrm{A} 1 \mathrm{~B} 2<\mu \mathrm{A} 2 \mathrm{~B} 2$ yang berarti bahwa siswa yang memiliki motivasi belajar rendah akan lebih akan memiliki keterampilan servis atas bola voli yang lebih baik jika diajar dengan gaya mengajar komando daripada dengan gaya mengajar inklusi. Dalam konteks ini dapat dimaknai bahwa kelebihan gaya mengajar komando sangat berpengaruh terhadap keterampilan servis atas bola voli, gaya mengajar komando akan lebih efektif diterapkan untuk siswa yang memiliki motivasi belajar rendah.

\section{PENUTUP}

\section{Kesimpulan}

Berdasarkan hasil pengolahan dan analisis data, maka kesimpulan dari hasil penelitian ini adalah (1) secara keseluruhan terdapat perbedaan keterampilan servis atas bola voli antara antara siswa yang diajar dengan gaya mengajar inklusi dan siswa yang 
diajar dengan gaya mengajar komando; (2) terdapat interaksi antara gaya mengajar dan motivasi belajar terhadap keterampilan servis atas bola voli; (3) bagi kelompok siswa yang memiliki tingkat motivasi belajar tinggi, keterampilan servis atas bola voli lebih tinggi bila diajar dengan gaya mengajar inklusi; (4) bagi kelompok siswa yang memiliki tingkat motivasi belajar rendah, keterampilan servis atas bola voli lebih tinggi bila diajar dengan gaya mengajar komando.

\section{Saran}

Berdasarkan kesimpulan dan implikasi penelitian, maka saran dari hasil penelitian ini adalah sebagai berikut (1) bagi guru penjas perlu menerapkan dan mengembangkan berbagai macam bentuk gaya mengajar, serta membuat pengelompokan kemampuan tiap variabel yang dimanipulasi agar menghasilkan hasil belajar maupun keterampilan yang baik; (2) perlu dilakukan penelitian lebih lanjut untuk mendapatkan gambaran yang lebih lengkap tentang faktor-faktor yang mempengaruhi keterampilan servis atas dalam permainan bola voli selain variabel yang diteliti.

\section{DAFTAR PUSTAKA}

Lenberg, K. (2006). Volleyball skills E drills: American volleyball coaches association. American: Human Kinetics.

Mukholid, A. (2007). Pendidikan jasmani olahraga dan kesehatan SMA kelas XII. Surakarta: Yudhistira.

Mosston, M. \& Ashworth, S. (2008). Teaching physical education. First Online Edition.

Purwanto, N. (2007). Psikologi pendidikan. Bandung: PT. Remaja Rosdakarya.

Sobur, A. (2013). Psikologi umum dalam lintasan sejarah. Bandung: Pustaka Setia.

Syah, M. (2007). Psikologi pendidikan dengan pendekatan baru. Bandung: PT. Remaja Rosdakarya.

Tangkudung, J. (2012). Kepelatihan olahraga. Jakarta: Cerdas Jaya.S. 